\title{
Performance Effects of Internal Audit Characteristics and Relationships in Nigerian Local Governments
}

\author{
Obal Usang Edet Usang \\ School of Accountancy, Universiti Utara Malaysia, Sintok 06010, Kedah, Malaysia \\ Email: usangobal@yahoo.com \\ Basariah Salim \\ School of Accountancy, Universiti Utara Malaysia, Sintok 06010, Kedah, Malaysia \\ Email: basa1189@uum.edu.my
}

Doi:10.5901/mjss.2016.v7n3p110

Abstract

The performance of local governments in Nigeria has been on the decline as service delivery to communities has become a challenged due to mismanagement and widespread corruption. Literature supports the value-adding role of internal audit and the ability of the function to enable an organization minimize opportunistic behaviours that are inimical to the performance of the organization. In view of this, the study examined the effect of internal audit characteristics and relationships on the performance of local governments in Nigeria. Self-reported questionnaires were used to obtain data from 301 heads of internal audit unit in local governments. The multiple regression analysis was utilized for testing the study's hypotheses. The results indicated that internal audit characteristics and internal audit relationship with management were positively and significantly related to performance. Also, collaboration between internal audit and external audit showed a negative and non-significant relationship with performance. Based on the findings, it was concluded that internal audit characteristics and internal audit relationship with management are important for internal audit value-adding capacity for improved performance of local governments in Nigeria.

Keywords: Performance, Nigerian public sector, internal audit characteristics, internal audit relationships

\section{Introduction}

The progress and survival of an organization hinges on critical factors. These factors shape the pattern of growth or performance of the organization. Extant literature asserts that performance in the public sector is driven by two main factors: resources and management (Boyne, 2003). Performance in the public sector is geared towards satisfaction of stakeholders whose needs are competing (Boschken, 1994). Thus, a combination of resources and management can ensure stakeholders' needs are met. In Nigeria, local governments have a varied list of stakeholders who make demands on her services. These stakeholders include communities, state and federal governments, and other non-governmental organizations, each demanding a transparent account of stewardship on the management and use of resources in the local government. Local governments were set up to enable grass-root development and wellbeing of communities through the effective channeling of available resources (Lawal, 2014). Local governments in Nigeria are statutorily expected to provide services such as health, education, sanitation, rural infrastructure, and undertake other developmental projects for administrative convenience.

Recently, local government councils in Nigeria have become the focus of constant debate as stakeholders express their dissatisfaction over the performance of these councils. Dwindling infrastructure, poor service delivery, corruption, mismanagement of financial resources which has resulted in debt and inability to pay worker's salaries have been reported (Achimugu, Stephen, \& Agboni, 2013; Emmanuel, Ajanya, \& Audu, 2013). Local governments have been struggling especially in the face of dwindling economic resources of the country. In order to address these problems, authors have suggested monitoring through strengthening internal controls, financial strategies, and ensuring that corrupt administrators are prosecuted (Lawal \& Oladunjoye, 2010; Olusola, 2011). However, this study suggests the exploring of other contextual factors which revolves around resources as contributors to the performance of local governments. Specifically, this study advocates the importance of resources for performance of local governments from the internal auditor's perspective. These resources include internal audit characteristics, internal audit relationship with management, 
collaboration between internal and external audit. It is also important to note that these variables interact to result in performance in local governments. Also, this would shed more light on internal audit value-adding role. Besides, internal audit characteristics and the function's relationship with other performance agents in the local government are valuable resources whose interrelations are important for performance improvement. These are resources within the local government that are yet to be harnessed to address performance failures in the local governments. Local governments in Nigeria are statutorily required to have an internal audit unit responsible for continuous audit in order to ensure laid down procedures are followed and resources are safeguarded. In carrying out these duties, the internal audit contributes to the performance of the local government. However, contribution to performance can only be guaranteed by having an internal audit with high-quality characteristics and the support of management. The relationship with management should be supportive where the right tools like funding, training and development are provided by management to enable the function continually improve on its quality and ability to appraise organization's processes. Also, relationship with management entails support for the function by way of responding to recommendations from audit and taking appropriate corrective actions. Evidence of internal audit contribution to performance is scarce as local governments are perceived as platforms for corrupt practices, little wonder the excessive interference of states in controlling local governments (Achimugu et al., 2013). Therefore, this study was borne out of concern for the seemingly lack of value-added by internal audit and to jointly examine the impact of the quality of internal audit, internal audits relationship with management, and collaboration with external audit on the performance of local governments.

This study contributes to knowledge in two ways. First, this study is beneficial to local government administrators as it emphasizes their role in strengthening internal audit and the importance of their supportive relationship to the performance of their local government councils. Secondly, the study gives an insight into the existing relationships between internal audit and external audit. Extant literature focused more on collaboration between internal audit and external audit in the private sector. Thus, this study provides additional knowledge on the effects of this relationship on performance in the public sector. Finally, from the theoretical point of view, the study affirms the centrality of resources as the basis for improvements in the performance of an organization. The rest of the paper is made up of a literature review on the study's constructs, the methodology adopted for the study, results and discussion, and conclusions of the study.

\section{Literature Review}

\subsection{Public Sector Performance}

Performance in the public sector relates to the ability of an organization to achieve set goals and provide quality services to citizens. Performance in the public sector can be financial or non-financial and based on the administration's focus at any point in time. Measuring performance in the public sector is complex as there are many stakeholders to be satisfied by limited resources. However, the important issue is how well have limited resources been managed to ensure efficiency, effectiveness, and quality of services. Bowerman and Hawksworth (1999) assert that the essence of local governments is to ensure the provision of high-quality services to grass root levels at an acceptable cost. Evaluating performance has also been associated with terms such as financial performance, the satisfaction of stakeholders, accountability, quality of service (Bratton, 2012; Brewer, 2006; Walker \& Boyne, 2006). A Meta-analysis of most important antecedents of performance in the public sector identified resources and management as main drivers of improvements in service performance (Boyne, 2003). In another study of Brazilian municipalities, resources and skills were identified as sources of higher performance. In view of this, internal audit characteristics and relationships were explored from the resource-based perspective in order to evaluate their effects on performance local government

\subsection{Theoretical Framework}

This study draws on the resource based view that resources are central to the competitive advantage of an organization (Barney, 1991; Grant, 1991). These resources include tangible and intangible resources. Tangible resources are physical resources that can easily be perceived and include: capital, financial, property, and plant. On the other hand, intangible resources are not easily perceived and according to Barney (1991), intangible resources are not easy to replicate because of their unique characteristics and are capable of helping an organization achieve sustained performance (Roberts \& Dowling, 2002). Intangible resources include an organization's reputation, skills, training, experience of workers, and relationships (formal and informal) within and outside the organization (Galbreath, 2005). Thus, internal audit characteristics, internal audit relationship with management, and collaboration with external audit are regarded as intangible resources capable of generating improved performance for local governments in Nigeria. Also, these relationships allude to the value-adding role of internal audit when properly harnessed and given the attention it deserves. 


\subsection{Internal Audit Characteristics and Performance}

Internal audit characteristics are those features which project the function as effective. These characteristics relate to skills, education, experience, professional certification, quality of internal audit work, independence, and training (Zain, Subramaniam, \& Stewart, 2006). Some of these characteristics are personal to the internal auditor while others are garnered over their years of experience in auditing. For example, experience, training, and certification are acquired over time. These characteristics are dynamic, and such, are in a state of continuous improvement over the career of an internal auditor. These characteristics enable the internal audit function to add value to an organization through their unique part in governance, risk, and control. Also, these characteristics determine the extent and perception of the quality of an internal audit function (Ege, 2015; Hutchinson \& Zain, 2009). A number of studies have found significant relationships between these characteristics and effectiveness of internal audit (Arena \& Azzone, 2009; Cohen \& Sayag, 2010). Some have related the existence of the function and its work of continuous auditing to performance (Aikins, 2011; Carmeli \& Tishler, 2004). Others have attributed the lack of these characteristics to corruption, mismanagement and general ineffectiveness of internal controls in the public sector (Emmanuel et al., 2013; Salawu \& Agbeja, 2007). However, studies linking these characteristics directly to performance in the public sector are limited. Therefore, from the resource-based perspective, internal audit skills, education experience, independence, training, professional certification and the quality of audits are unique resources that contribute to improvement in the operations of an organization. Hence, this study proposes that internal audit characteristics have a significant relationship with performance of local governments.

\subsection{Collaboration between Internal and External Audit}

Collaboration refers to a relationship where internal and external audit cooperate during audits by giving each other access to working papers and the external auditor relies on the work of the internal auditor (Brody, Golen, \& Reckers, 1998; Zain et al., 2006). It is a mutual relationship which fosters efficiency in the audit process and creates value for the organization. Studies have shown that the external auditor reliance on the internal audit can lead to audit fees reduction and minimized audit lag (Abbott, Parker, \& Peters, 2012; Wood, 2004). This collaboration has also been shown to decrease earnings management and improve financial reporting quality (Prawitt, Smith, \& Wood, 2009). Also, a positive relationship was reported between internal audit contribution to financial statement audit and a close relationship between internal and external audit (Zain et al., 2006). In addition, observations and recommendations during the audit are easily taken up with management, and organizational processes are improved for better performance. In view of this, collaboration between internal and external audit has a significant influence on the performance of local governments.

\subsection{Internal Audit-Management Relationships}

In order to be effective, internal auditors are expected to have a working relationship with management and auditees. This relationship should be characterized by mutual respect and congruence of goals in terms of enhancing the operations of the organization. According to IIA's competency framework, the internal audit is expected to use persuasion, collaboration and communication to secure and create an atmosphere conducive for audits (Institute of Internal Auditors, 2013). This requires the building of relationships within the organization with management and other auditees. Such relationships should build trust and reduce resistance to audit while enhancing the audit process and value added to the organization (Chambers \& McDonald, 2013). Also, another study suggested that to be effective, internal audit relationship with management is important (Mihret \& Yismaw, 2007). The internal audit does not operate in a vacuum, management and auditees' cooperation is required for the activities of the function to result in enhanced processes for the organization. Thus, an atmosphere characterized by low support and suspicion constraints internal audit's ability to contribute to the performance of the organization. An effective relationship between internal audit and management includes internal audit access to information, appreciation of internal audit activities, implementing internal audit's recommendations and observations, and ensuring adequate preparations for audit (Elliott, Dawson, \& Edwards, 2007). Ahmad, Othman, Othman, and Jusoff (2009) found that a supportive relationship from management ranked the second most influential factor after the quality of internal audit in determining the effectiveness of internal audit in the Malaysian public sector. Therefore, internal audit and management relationship has a significant influence on the performance of local governments. 


\section{Method}

This study's design is descriptive as it sought to elaborate on the features of the issue being studied with a view to arriving at generalizations for the study's population (Kumar, Talib, \& Ramayah, 2013. Heads of internal audit unit in the local governments across the country were chosen to respond to the survey instrument because of their position as heads of audit and are part of management team in the local government. Hence, they possessed the needed experience to respond to the factors examined in this study. In addition, heads of internal audit are considered as the appropriate respondents because of the nature of variables being studied. Similar researches used heads of internal audit as respondents. For example, Aikins (2011) surveyed internal audit directors and managers in examining the relationship between internal audit role and improvement in financial performance in the US. The measurement of the variables of this study was derived from previous researchers. The study utilized a survey of heads of internal audit units in Nigerian local governments. Six hundred questionnaires were randomly distributed to heads of internal audit units in Nigerian local governments, a total of 323 were returned while 301 were considered suitable for analysis. The questionnaires were based on a five-point scale ranging from 1 "strongly disagree" to 5 "strongly agree". Initial analysis showed there was no problem of response bias between early and late respondents. Also, missing items were replaced using mean replacement as recommended by Hair, Black, Babin, and Anderson (2010). Furthermore, descriptive statistics of variables and respondents' profile analysis were conducted. Multiple regression was also conducted for testing the study's hypotheses. The constructs reliability was assessed using Cronbach's alpha. All the constructs had reliability ranging from .82 to .87. According to Hair et al. (2010), a Cronbach alpha .70 and above is acceptable.

\subsection{Variable Measurements}

\subsubsection{Performance}

The performance of local government was measured as a unidimensional construct consisting of financial and nonfinancial aspects of performance. Eight items in all were adapted from Brewer (2006) and Maher and Deller (2011) to measure performance.

\subsubsection{Internal Audit Characteristics}

Internal audit characteristic was measured as a unidimensional construct consisting of education, experience, independence, quality of work, and training. A total of ten items were adapted from Cohen and Sayag (2010) and Elliott et al. (2007) for measuring internal audit characteristics.

\subsubsection{Collaboration between Internal and external audit}

The measurement of collaboration between internal and external audit was based on the features of a collaborative relationship and consists of aspects such as collaboration on areas of audit coverage and work schedules, free access to working papers and letters, and efficiency of collaboration. In all, five items were adapted from Goodwin (2004) and Zain et al. (2006).

\subsubsection{Internal audit and management Relationship}

Internal audit relationship with management was based on the extent to which the function is appreciated and the cooperation it gets within the organization. Four items measuring this construct were adapted from Elliott et al. (2007) and Mihret and Yismaw (2007).

\subsection{Respondent's characteristics}

The respondents' characteristics showed that in terms of professional certification, 189 (62.8\%) had professional certification and $112(37.2 \%)$ had no professional certification. Also, regarding specific experience in internal audit, 142 (47.1\%) had between 1-5 years experience, 108 (35.9\%) had between 5-10 years experience, 40 (13.3\%) had above 10 years experience, while $11(3.7 \%)$ did not provide information on their experience in internal audit. With respect to education, most of the respondents $97.3 \%$ had a first degree while $2.7 \%$ had other qualifications. On the area of 
specialty, $223(74.1 \%)$ had accounting and auditing specialty, 65 (21.6\%) had finance and economics specialty while 13 (4.3\%) had specialty other than the first two groups. The respondents' characteristics are presented in Table 1.

Table 1. Respondents Characteristics

\begin{tabular}{lcc}
\hline Item & Frequency & Percentage (\%) \\
\hline Professional Certification & 189 & \\
Professional certificate & 112 & 62.8 \\
None & & 37.2 \\
Specific experience in Internal audit & 142 & \\
1-5 years & 108 & 47.1 \\
5-10 years & 40 & 35.9 \\
Above 10 years & 11 & 13.3 \\
No information & & 3.7 \\
Education & 293 & \\
First Degree & 8 & 97.3 \\
Others & & 2.7 \\
Area of Specialty & 223 & 74.1 \\
Accounting and Auditing & 65 & 21.6 \\
Finance and Economics & 13 & 4.3 \\
Others & & \\
\hline
\end{tabular}

\section{Findings and Discussion}

\subsection{Descriptive Statistics}

The descriptive statistics of variables showed that the mean of the variables ranged from 2.78 to 3.76 . The variance of the variables also ranged from .423 to .736 while standard deviation ranged from .651 to .858 . Furthermore, skewness and kurtosis values of the variables showed that the distribution was normal as none exceeded the recommended point of \pm 2.58 (Hair et al., 2010). Table 2 shows the descriptive statistics of the variables.

Table 2. Descriptive Statistics

\begin{tabular}{ccccccc}
\hline Variables & Items & Mean & Variance & Std. Dev. & Skewness & Kurtosis \\
\hline LGP & 8 & 2.78 & .553 & .743 & .457 & -.138 \\
IAC & 10 & 3.61 & .423 & .651 & -.774 & 1.180 \\
CIAEA & 5 & 3.76 & .736 & .858 & -1.212 & 1.600 \\
IAMR & 4 & 3.68 & .676 & .822 & -.793 & .135 \\
\hline
\end{tabular}

Note: LGP = local government performance; IAC = internal audit characteristics; CIAEA = collaboration between internal and external audit; IAMR = internal audit and management relationship.

\subsection{Correlations between variables}

Furthermore, Pearson Production Moment correlation was performed on the variables in order to examine the association amongst the variables. The results showed that all the correlations among the variables were below .80. Correlations of .80 and above among variables are considered a problem because of multicollinearity (Hair et al., 2010). Furthermore, the variance inflation factor (VIF) of the variables ranged from 1.39 to 2.00 while tolerance values ranged from .50 to .72 . Hence, there was no problem of multicollinearity among the variables of the study given that tolerance values were within the acceptable limits of not less than .10 and VIF was less than 10 (Hair et al., 2010). The correlation results are presented on Table 3. 
Table 3. Correlations

\begin{tabular}{ccccc}
\hline Variable & LGP & IAC & CIAEA & IAMR \\
\hline LGP & 1.000 & & & \\
IAC & $.298^{*}$ & 1.000 & & \\
CIAEA & $.119^{*}$ & $.476^{*}$ & 1.000 & \\
IAMR & $.321^{*}$ & $.644^{*}$ & $.454^{*}$ & 1.000 \\
\hline
\end{tabular}

Note: $\mathrm{LGP}=$ local government performance; IAC = internal audit characteristics; $\mathrm{CIAEA}=$ collaboration between internal and external audit; IAMR = internal audit and management relationship. ${ }^{*} p<.05$

\subsection{Regression Result}

Multiple regression was conducted to examine the relationship between the independent variables and the dependent variable of the study. The results are presented in Table 4.

Table 4. Regression Results

\begin{tabular}{cccccc}
\hline Variable & Beta Coefficient & Standard Error & t-statistic & P-value & Remarks \\
\hline Constant & 1.492 & .239 & 6.23 & $.000^{*}$ & Sig \\
IAC & .206 & .084 & 2.43 & $.016^{*}$ & Sig \\
CIAEA & -.062 & .052 & -1.18 & .240 & Not sig \\
IAMR & .202 & .062 & 3.28 & $.001^{*}$ & Sig \\
R & & & .347 & & \\
R $^{2}$ & & & .121 & & \\
Adj. R & & & .113 & & \\
F-value & & 13.69 & $.000^{*}$ & Sig \\
n & & & 301 & & \\
\hline
\end{tabular}

Note: $\mathrm{LGP}=$ local government performance; IAC = internal audit characteristics; CIAEA = collaboration between internal and external audit; IAMR = internal audit and management relationship. ${ }^{*} p<.05$

From Table 4, the model is significant with $F(3,297)=13.69$ and $p<.05$. This indicates a linear relationship between the independent and dependent variables of the study. The adjusted r-squared of the model is .113, indicating that $11.3 \%$ of the variance in the performance of local government is explained by internal audit characteristics, collaboration between internal and external audit, and internal audit and management relations. Also, the results showed that the internal audit characteristics and internal audit relationship with management were positively and significantly related to the performance of local government's performance in Nigeria. Furthermore, collaboration between internal and external audit had a negative and non-significant relationship with performance of local governments in Nigeria.

Internal audit characteristics showed a significant and positive relationship with local government performance in Nigeria, thus, hypothesis one is accepted ( $t$-value $2.43, p<.05)$. The findings agree with the resource-based theory that competencies, skills and capabilities of human resource within an organization are critical for organizational performance (Barney, 2001). Also, the study supports Ege (2015) that the quality of internal audit can deter management excesses and contribute to the health of the organization. Thus, the higher the internal audit characteristics, the more the contribution to improved performance of an organization.

Also, the findings showed a positive and significant relationship between internal audit and management relationship and performance ( $t$-value $3.28, p<.05)$. This finding suggests that the relationship between internal audit and management is important for performance of an organization. The finding supports previous studies of Al-Twaijry, Brierley, and Gwilliam (2003) and Arena and Azzone (2009). Al-Twaijry et al. (2003) found the lack of support from management limited the scope of internal audit and reduced the function's ability to contribute to the organizations studied. On the other hand, a supportive relationship between management and internal audit was found to be important for internal audit effectiveness. Thus, a working relationship between internal audit and management enables the internal audit function to carry out actions that help improve organizational performance. Theoretically, relationships within an organization: formal and informal are considered intangible resource which when properly harnessed can generate more performance for the organization (Grant, 1991). Thus, a good relationship between internal audit and management, where management supports the function by implementing recommendations and corrective actions, would enhance performance of the organization.

Furthermore, the results showed a negative and non-significant relationship between collaboration between 
internal and external audit (t-value $-1.18, p>$.05). This finding suggests that collaboration between internal and external audit had a negative effect on performance of the local governments. This finding is unexpected as extant literature suggest that collaboration enhances the efficiency of the audit, reduces audit fee, audit report lag, and reduces material misstatements which affect the performance of the organization (Hajiha \& Rafiee, 2011; Morrill \& Morrill, 2003; Singh \& Newby, 2010). However, this result could also suggest that there is inadequate collaboration between internal and external audit. Furthermore, similar studies on collaboration between internal and external audit are mostly in the private sector and since this study was conducted in the public sector, results may differ. The findings of this study showed that internal audit characteristics, and internal audit and management relationship are important for performance improvement. Also, a cordial and supportive relationship between internal audit and management can enhance the function's ability to execute processes that lead to improved performance and success of the organization. However, an atmosphere of animosity and poor support by management will rob an organization of the value-adding characteristic of internal audit.

\section{Conclusions and Implications}

According to extant literature, the critical factors for internal audit value adding role includes its characteristics and relationships with management and external audit. From the findings of this study, the internal audit characteristics and internal audit relationship with management are very important factors for local government performance in Nigeria. Improving on the internal audit characteristics through supportive funding, training, and supportive relationship with management will help limit the incidence of performance failures currently being experienced by local governments in Nigeria. Thus, local administrators should foster an environment which supports the work of the internal audit function. This can be achieved by exposing the internal audit staff to training and experiences that strengthen the function. Although the relationship with external audit was not significant, a cordial relationship with the external audit is important for internal auditor's perception within the organization. This study has obvious limitations as the sample was made up of only heads of internal audit unit. Future studies may consider sampling other unit heads. This may yield further evidence on the relationships examined here. Also, future studies may consider exploring other reasons the relationship between collaboration between internal and external audit was negative and not significant in this study.

\section{References}

Abbott, L. J., Parker, S., \& Peters, G. F. (2012). Internal audit assistance and external audit timeliness. Auditing: A Journal of Practice \& Theory, 31(4), 3-20. doi:10.2308/ajpt-10296

Achimugu, H., Stephen, M. R., \& Agboni, U. J. (2013). Local government service delivery in Nigeria: An empirical comparison of government efforts and the people's expectations. Mediterranean Journal of Social Sciences, 4(6), 335-346. doi:10.5901/mjss. 2013.v4n6p335

Ahmad, H. N., Othman, R., Othman, R., \& Jusoff, K. (2009). The effectiveness of internal audit in Malaysian public sector. Journal of Modern Acounting and Auditing, 5(9), 53-63.

Aikins, S. K. (2011). An examination of government internal audits' role in improving financial performance. Public Finance and Management, 11(4), 306-337.

Al-Twaijry, A. A. ., Brierley, J. A., \& Gwilliam, D. R. (2003). The Development of Internal Audit in Saudi Arabia: An Institutional Theory Perspective. Critical Perspectives on Accounting, 14(5), 507-531. doi:10.1016/S1045-2354(02)00158-2

Arena, M., \& Azzone, G. (2009). Identifying organizational drivers of internal audit effectiveness. International Journal of Auditing, 13, 43-60.

Barney, J. (1991). Firm resources and sustained competitive advantage. Journal of Management, 17(1), 99-120.

Barney, J. B. (2001). Is the resource-Based "view" a useful perspective for strategic management research? Yes. The Academy of Management Review, 26(1), 41-56.

Boschken, H. L. (1994). Organizational performance and multiple constituencies. Public Administrative Review, 54(3), 308-312.

Bowerman, M., \& Hawksworth, S. (1999). Local government internal auditors' perceptions of the Audit Commission. Managerial Auditing Journal, 14(8), 396-407. doi:10.1108/02686909910301466

Boyne, G. A. (2003). Sources of public service improvement: A critical review and research agenda. Journal of Public Administration Research and Theory, 13(3), 367-394. doi:10.1093/jopart/mug027

Bratton, M. (2012). Citizen perceptions of local government responsiveness in Sub-Saharan Africa. World Development, 40(3), 516-527.

Brewer, G. A. (2006). All measures of performance are subjective: More evidence on US federal agencies. In G. A. Boyne (Ed.), Public service performance: Perspectives on measurement and management (pp. 35-54). Cambridge: University Press.

Brody, R., Golen, S., \& Reckers, P. (1998). An empirical investigation of the interface between internal and external auditors. Accounting and Business Research, 28(3), 160-171.

Carmeli, A., \& Tishler, A. (2004). The relationships between intangible organizational elements and organizational performance. 
Strategic Management Journal, 25(13), 1257-1278. doi:10.1002/smj.428

Chambers, R., \& McDonald, P. (2013). Cultivating soft skills ". Internal Auditor, 70(3), 45-50.

Cohen, A., \& Sayag, G. (2010). The effectiveness of internal auditing: An empirical examination of its determinants in Israeli organisations. Australian Accounting Review, 20(3), 296-307. doi:10.1111/j.1835-2561.2010.00092.x

Ege, M. S. (2015). Does internal audit quality function quality deter management misconduct? The Accounting Review, 90(2), 495-527. doi:http://dx.doi.org/10.2308/accr-50871

Elliott, M., Dawson, R., \& Edwards, J. (2007). An improved process model for internal auditing. Managerial Auditing Journal, 22(6), $552-$ 565. doi:10.1108/02686900710759370

Emmanuel, O. E., Ajanya, M. A., \& Audu, F. (2013). An assessment of internal control audit on the efficency of public sector in Kogi State Nigeria. Mediterranean Journal of Social Sciences, 4(11), 717-726. doi:10.5901/mjss.2013.v4n11p717

Galbreath, J. (2005). Which resources matter the most to firm success? An exploratory study of resource-based theory. Technovation, 25, 979-987. doi:10.1016/j.technovation.2004.02.008

Goodwin, J. (2004). A comparison of internal audit in the private and public sectors. Managerial Auditing Journal, 19(4), 640-660. doi:10.1108/02686900410537766

Grant, R. M. (1991). The resource-based theory of competitive advantage: Implications for strategy formulation. California Management Review, 114-135.

Hair, J. F. J., Black, W. C., Babin, B. J., \& Anderson, R. E. (2010). Multivariate data analysis: A global perspective (7th ed.). New Jersey: Pearson Prentice Hall.

Hajiha, Z., \& Rafiee, A. (2011). The impact of internal audit function quality on audit delays. Middle-East Journal of Scientific Research, 10(3), 389-397.

Hutchinson, M. R., \& Zain, M. M. (2009). Internal audit quality, audit committee independence, growth opportunities and firm performance. Corporate Ownership and Control, 7(2), 50-63.

Institute of Internal Auditors. (2013). The IIA 's Global Internal Audit Competency Framework. Altamonte Springs: The Institute of Internal Auditors. [Online] Available: https://na.theiia.org/about-us/Public Documents/The IIA Global Internal Audit Competency Framework.pdf (October 14, 2015)

Kumar, M., Talib, S. A., \& Ramayah, T. (2013). Business research methods. Oxford Fajar: Oxford University Press.

Lawal, T. (2014). Local government and rural infrastructural delivery in Nigeria. International Journal of Academic Research in Business and Social Sciences, 4(4), 139-147.

Lawal, T., \& Oladunjoye, A. (2010). Local government, corruption and democracy in Nigeria. Journal of Sustainable Development in Africa, 12(5), 227-235.

Maher, C. S., \& Deller, S. C. (2011). Measuring municipal fiscal condition: Do objective measures of fiscal health relate to subjective measures? Journal of Public Budgeting, Accounting \& Financial Management, 23(3), 427-450.

Mihret, D. G., \& Yismaw, A. W. (2007). Internal audit effectiveness: an Ethiopian public sector case study. Managerial Auditing Journal, 22(5), 470-484. doi:10.1108/02686900710750757

Morrill, C., \& Morrill, J. (2003). Internal auditors and the external audit: A transaction cost perspective. Managerial Auditing Journal, $18(6 / 7), 490-504$.

Olusola, O. (2011). Boosting internally generated revenue of local governments in Ogun State, Nigeria ( A study of selected local governments in Ogun State ). European Journal of Humanities and Social Sciences, 8(1), 336-348.

Prawitt, D. F., Smith, J. L., \& Wood, D. A. (2009). Internal audit quality and earnings management. The Accounting Review, 84(4), 12551280.

Roberts, P. W., \& Dowling, G. R. (2002). Corporate reputation and sustained superior financial performance. Strategic Management Journal, 23, 1077-1093. doi:10.1002/smj.274

Salawu, R. O., \& Agbeja, O. (2007). Auditing and accountability mechanism in the public sector. The International Journal of Applied Economics and Finance, 1(1), 45-54.

Singh, H., \& Newby, R. (2010). Internal audit and audit fees: further evidence. Managerial Auditing Journal, 25(4), 309-327. doi:10.1108/02686901011034153

Walker, R. M., \& Boyne, G. A. (2006). Public management reform and organizational performance: An empirical assessment of the U. K. labour government's public service improvement strategy. Journal of Policy Analysis and Management, 25(2), 371-393. doi:10.1002/pam

Wood, D. A. (2004). Increasing value through internal and external auditor coordination. IIA Research Foundation. [Online] Available: https://global.theiia.org/about/about-the-iia/Public Documents/Sawyer_Award_2004.pdf (October 22, 2014)

Zain, M. M., Subramaniam, N., \& Stewart, J. (2006). Internal auditors ' assessment of their contribution to financial statement audits: The relation with audit committee and internal audit function characteristics. International Journal of Auditing, 10, 1-18. 